\title{
Going to Meet James Baldwin in Provence
}

\author{
D. Quentin Miller Suffolk University, Boston
}

\begin{abstract}
The author travels to St.-Paul-de-Vence, the site of Baldwin's final decades, with the intention of understanding expatriation and/or exile more deeply. The intention of this visit is to fill in some of the gaps in Baldwin's official biographies, which do not tend to dwell on his time spent in Provence as much as his time in Paris, Turkey, New York, and elsewhere. By interviewing a woman who knew Baldwin well during those years, the author manages to add new layers to his understanding of Baldwin's late years, but finally arrives at the understanding that writing (rather than analyzing) is the main goal of the expatriate writer. Inspired by Baldwin's muse, he stops contemplating his subject and gets to work, finally connecting the act of writing to expatriation by doing it.
\end{abstract}

Keywords: Provence, St.-Paul-de-Vence, expatriation, Southern France, exile, James Baldwin

You have to write somewhere.

That may seem obvious, but in the age of the Internet writing takes place everywhere, and it has devolved for many of us into grunting communication. Real writing requires a private space, a room of one's own, as Virginia Woolf argued. Writers tend to emerge from such spaces for experience and inspiration before returning (or retreating) to get their writing done. Real writing of the type James Baldwin did involves labor and concentration, and it has something to do with the place where it is created.

Those of us who are devoted to literature nearly worship the places associated with authors. When we travel, we visit their museum-like houses and swoon over their belongings. "That was his pen! That was her lamp!" I've belonged to author societies in which the primary activity is to explore the places that inspired the writers we love. Such societies invariably hold their conferences 
someplace associated with that writer. I once led a course in Paris on the American writers who wrote there. There's something magical about discussing The Sun Also Rises and Giovanni's Room in Brasserie Lipp where both Hemingway and Baldwin liked to drink.

So it didn't strike me as that unusual to uproot myself for a month to go ghost-chasing after Baldwin, an author I'd been writing about for virtually all of my career. I have read all of his books to the point that I've had to tape the bindings together, but I wanted something else, something that came from being where he had been. As we know, he had been around the world.

Magdalena Zaborowska, in her recent book James Baldwin's Turkish Decade: Erotics of Exile (2009), successfully demonstrates the deep imprint of Baldwin's years in Istanbul on his mid-career work. ${ }^{1}$ Zaborowska not only studied Baldwin's texts, but followed in his path, meeting those who knew him in Turkey. I sought to extend her project into Baldwin's late career by tracing his footsteps through his final site of expatriation: St.-Paul-de-Vence, a hill town in southern France, near Nice.

Despite his success and a reputation for extravagant, impulsive purchases, Baldwin only bought one house (for himself) in his lifetime. That housesprawling, ancient, made of stone-was in St.-Paul. He had been brought there in 1970 for his health, and at first rented out all of the rooms one by one to accommodate his visiting friends. Although he remained, to use his term, a "transatlantic commuter"2 through the final seventeen years of his life, returning occasionally to the States to teach college courses, give lectures, conduct research, and stay with friends, and although he declared in a 1977 New York Times interview that he was planning to return to New York, ${ }^{3}$ he stayed in St.-Paul-deVence, surrounding himself with friends and family. He died in his French house in the hills, overlooking the Mediterranean.

In his biography Talking at the Gates, James Campbell (who visited Baldwin on more than one occasion in St.-Paul), is struck by the fact that "not a word is said, in the whole lot [of books published between 1971 and 1976], about his present life in France." His final two novels are also notable for "the absence of any mention of Baldwin's current mode of life." Campbell is much more pleased with Baldwin's unpublished final play The Welcome Table, which is set in a house in southern France, than he is with any of Baldwin's denigrated works published in his final decade: the novel Just Above My Head (1979), the extended essay The Evidence of Things Not Seen (1982), and the poetry collection Jimmy's Blues (1985). Campbell's assessment is heavily influenced by his status as a biographer frustrated with the fact that Baldwin largely refused the opportunity to write about his immediate surroundings in his waning years. Like me, Campbell wanted a tangible connection between place and literary text. I wouldn't fully "get” Baldwin, I thought, until I saw his world.

I set out in the summer of 2013, more than a quarter-century after Baldwin's death, to see what he saw in Provence in order to understand what the place did for him, even if it did not provide immediate source material for his 
writing. My journey was an opportunity to reflect on the condition of expatriation as it impacted Baldwin's life, to think deeply about why certain writers need to move away from their home countries even while continuing to write about them. These writers include some of the greatest of the twentieth century: Joyce, Wharton, Hemingway, Marquez, Nabokov, Stein, anyone who ever emigrated ... the list is enormous. In fact, writers who never left their homes are much less common: Dickinson and Proust are outliers. Few writers got around as much as Baldwin did, though. As a result, "home" was always an abstract idea and a touchy subject for him.

I tripped over Baldwin's defensive retort to an interviewer from Black Scholar in 1973 who goaded him about his decision to live in the south of France while the struggle of oppressed blacks continued; he said, "I am not in exile and I am not in paradise. It rains down here, too." ${ }^{\text {"T }}$ The word "exile" does attach itself to Baldwin from time to time, and his initial decision to move to Paris was based largely on his decision to flee the United States because of the rage he felt in response to institutionalized racism (i.e. segregation) ${ }^{7}$ as well as less evident forms of discrimination, including racial profiling and homophobia. In the essay "Every Good-Bye Ain't Gone," he says that his decision to leave the States (his first "departure," as he calls it here) wasn't really a choice: "I had to leave." ${ }^{8}$ We tend to think of exiles as being motivated by political oppression, but there's a fuzzy line between oppression sanctioned by governments and a general feeling that one cannot flourish as a writer or artist of any kind under certain cultural circumstances. His defensiveness in 1973, though, had to do with a charge that was leveled at him often: while the hope of the 1960s turned into the blight and cynicism of the 1970s, Baldwin was not to be found reporting from the front lines, as he had done frequently (if not perpetually) a decade earlier.

Baldwin didn't take well to labels of any kind, and he might have bristled at the term "expatriate" in addition to "exile." My aim was not to decide whether Baldwin was a writer in exile, or an expatriate writer, or a writer who took refuge from the battle for black empowerment (a charge implicit in the 1973 interviewer's question). Baldwin simply cannot be simplified. My aim was to meditate, through Baldwin, on the impulse writers follow to live abroad. In order to do so, I became a temporary expatriate, taking a month away from my family and my routine to see southern France with writing, not vacationing, in mind. I summoned Baldwin's spirit in order to fill in what remains a critical empty space.

It does rain in St.-Paul-de-Vence. I discovered that fact in no uncertain terms as I rode eastward through Provence, on the slow train from Marseilles, which was even slower that day due to an unexplained hour-long wait in the station. Everyone who has gone anywhere has had a similar experience. C'est la vie. Travel isn't comfortable or predictable: a baby was wailing, the car was hot and crowded, I was hungry, the guy next to me was snoring. We've all been there. 
The delay was just long enough to allow the bright blue skies to cloud over abruptly, then to open up at the exact moment I arrived in Nice. In my limited French, I learned how to get to the bus stop. It was a ten-minute walk, fifteen for someone in less of a hurry than I was. My wheeled luggage sprayed water from the tiles underfoot, ensuring that every inch of me was soaked. "The south of France isn't as sunny as most people think it is," Baldwin had retorted to that interviewer.

He was, of course, not speaking of the weather, and neither should I be, for although weather is the most clichéd question asked of any traveler, it's also the least interesting thing to talk about. The aim of my journey was to find Baldwin, not to care whether my socks were wet. I was operating under the assumption that "You got to go there to know there," but going there involves effort. I slumped into a seat-turned-puddle as the bus made its short but slow journey away from the Mediterranean and into the hills.

The bus ride was actually the end of a journey, one I'd been on a long time. I started studying Baldwin when I was twenty-five, more than two decades ago. Now mid-life and mid-career, I have been immersed in his works ever since. I might not go so far as to call it an obsession, but my interest in him has been deep and abiding.

The physical journey came halfway through my own month of expatriation. I had been granted a visiting professorship at the Université-Paul-Valery in Montpellier. This was a fairly low-demand appointment: I had to give a talk and was scheduled to give a conference paper at the end while organizing another conference for the following year (all on Baldwin). I consulted with some graduate students, but was otherwise fairly free to get my writing done. I had many writing projects going on, some critical, some creative. One was brand new territory: a blog about my experiences. I called it "What's an Expat? A Month In France In Search Of. .." The trailing off at the end of the title should probably have been filled in with "James Baldwin," but he wasn't exactly who or what I was searching for. It involved him, yes, but it also involved a deeper curiosity about expatriate writers. I have been fascinated by a few of themWharton, Hemingway, Fitzgerald, as well as the man in question-and I could see common features in their writing, but I didn't know what it was like to be an expatriate. You got to go there to know there.

In the weeks leading up to my journey to St.-Paul-de-Vence, I had begun to develop some insights and to record them on the blog. I wasn't great at blogwriting at first, having not read many blogs avidly, but I warmed up to it. Writing every day kept me anchored, and served as a warm-up exercise for the other writing I was doing. My subjects were varied: language, the attraction to things medieval, food, cycling, the way I inadvertently offended or threatened people in the Arab Quarter, same-sex marriage (which happened for the first time in France while I was there, in the very city where I was staying), to name a few. Soon I had a significant number of followers, strangers as well as friends. 
Maybe blogging wasn't so bad. Maybe I could keep one at home, once this magical if lonely month was over.

But no. The blog was a product of the journey, not just a record of it. Removing myself from my family, my routine, my comfort zone, and my homeland had opened up spaces for me that wouldn't have been there otherwise. And those spaces included temporal space-I was taking more time to really write with focus and concentration-and creative space. I was on a roll. But I had a job to do, the ostensible reason for being here in the first place: to deepen my understanding of my author of interest. I packed my bags and boarded the train, then took that rainy walk in Nice, and finally finished the bus ride that brought me to my destination.

Here I was at last, steps from where Baldwin had lived for so long on Rue de la Colle, and where he had breathed his last breath. I checked into Le Hameau hotel, where he had lived for six months prior to his purchasing the house across the street. I felt a little frisson of excitement knowing that he walked on the same stones, saw the same views, sat in the same cafés that surrounded me. But one question troubled me: was his ghost roaming the landscape, or did I bring it here?

The next morning the sun was back. I strolled across the street to peek at his house. Often described as unkempt by visitors in Baldwin's lifetime, it's now overgrown, barely visible from the padlocked gate through the vegetation. The Baldwin family no longer owns it. His brother David continued to live here until his death a few years ago. In an article in Architectural Digest published just a year before his death, Baldwin discusses his house. He springboards from the cliché "a house is not a home" to say, "it can become only, I suppose, a space to be manipulated." ${ }^{10}$ I thought of these words as I peered at the place. Why wasn't it a home? Manipulated how? What did this place do for him, for his creative spirit? That's what I wanted to know.

"Home," Baldwin implies, is a state of mind more than it is a built shelter on a piece of property. To be home is to feel secure. To feel rested. To be wellsurrounded by that which comforts you. I looked beyond the house itself (which wasn't terribly available to me unless I were to vault over the wall, which I considered doing) and into the town. It was also his "home." I can easily see how Baldwin felt secure, rested, and comfortable in this ancient, walled fortress. He denied, in that 1973 interview, that he had found a "haven" or a "paradise." And yet, given that he grew up impoverished in Harlem during the Great Depression, it's easy to imagine that he felt that this place had moved a great distance in that direction. According to his biographers, he called his studio "the torture chamber," 11 underscoring the argument that he (and many writers) advance that writing is very hard work. But despite the "Donjon" at the center of St.-Paul, torture is hard to imagine here, a charming town saturated with art galleries, restaurants, beautiful views, and little else.

Like the rain Baldwin spoke of, the torture came mostly from within. 
Much of what can be gleaned of Baldwin's time in St.-Paul has been covered by three of his biographers (Wetherby, Campbell, Leeming), all of whom knew him when he lived here, and all of whom visited. David Leeming, who had served as Baldwin's secretary for a time, was with Baldwin in his dying days and writes movingly about them at the end of his biography. ${ }^{12}$ Nicholas DelBanco's work of non-fiction Running in Place contains some supplemental scenes that complete the picture of Baldwin's time in southern France, which looks something like this:

Baldwin, in the 1970s and 1980s, led an exhausting social life in St.-Paul characterized by constant visitors and late night parties. He was prone to more chaos than usual in those years. Emotionally, he had worn thin, following the assassinations of black leaders, the demands of fame, the disastrous outcome of a failed partnership with Hollywood, and his ongoing search for long-term companionship. He committed to many more speaking engagements than he could handle. He developed a reputation for arriving late to them, or for canceling at the last minute, with apologies. His finances were a mess: he had to hire others to try to manage them. His desire for romantic companionship led to relationships that were at best dead ends, and at worst destructive. His commitment to causes was fickle. He continued to write with the same fervor as ever, but he started many more writing projects than he finished. A lifetime of drinking and smoking were taking their toll on his body.

I knew from the biographies that his home away from home in St.-Paul was its most famous hotel and restaurant, the Colombe D'Or. The hotel is still in the family, who were great friends with Baldwin. One of the three children is named Pitou, an artist who was thirteen when she first met Baldwin. I made an appointment and asked Pitou to tell me everything she remembered about Baldwin, starting anywhere. She said she didn't like to talk about it, and asked me not to record our conversation. Of course. Whatever you say. Recorder off. She got espressos for each of us, lit a cigarette, and fell into a reverie.

This hotel is a landmark, easily the most famous building in St.-Paul-de-Vence. An elegant and unique place, like the man who would frequent it throughout his years here. As Pitou and I sought some privacy at a table in a back room, tourists and guests occasionally wandered through, peering at the works of creative genius on the walls, plumbing their mystery. The story goes that the great artists of the early twentieth century (Matisse, Miro, Chagall, Braque) would pay for their stay or meals there with artworks rather than cash. However it got there, original art hangs on the walls, in jaw-dropping abundance. It's as much museum as hotel.

We settled in and I fell silent as she warmed to the subject that she supposedly didn't like to talk about. She brought him to life through her stories: I sensed that Baldwin was in the room with us, listening, grinning that outrageous grin that promised to explode into a laugh. I learned that Baldwin was, for Pitou, an almost indescribable figure of awe and inspiration, warmth, and something more immediate: mentor, friend, teacher, shaman. He spent many, many nights at the bar of the Colombe D'Or. He held his sixtieth birthday party there. 
His legendary drinking was not exaggerated: she confirmed it through many anecdotes. He and the famous French film actress Simone Signoret, who also lived here, would match each other drink for drink, and talk, and laugh, and yell, until all hours of the morning. They lived and died the same way: fully, then too quickly.

Pitou recalled one evening when Baldwin put his hand on her wrist and said, "I'm going to tell you all about your life. I've figured it out." This intense conversation, or lecture, started before midnight and went on until eight in the morning. The sun was coming up. She was working at the hotel, and they had finished countless bottles of rosé wine. She couldn't keep up with all of the advice, so exhausted was she by the end, but she remembered him booming, and repeating, the line, "Build your life on what has been destroyed!" She repeated it again to me and broke into laughter. "Can you imagine?" I could, somehow.

These were wild times. Pitou remembered first meeting Baldwin, who blew into the hotel bar with the universe trailing behind him. She looked off wistfully, between stories that caused her to break into peals of laughter, her green eyes twinkling. "I'll never meet anyone like him again." She used the word "clever" to describe him. Warm. Someone who cared about everyone. Who wasn't impressed by the famous, important people in the room, but who would single out the shy, or self-conscious, and listen to their story. "He was so full of life! So full of life, my God!" Pitou and her mother were with him at the end. Baldwin told Pitou's mother, just hours before he died, that he was bored. "Dying was boring." Because life was so interesting? I prompted. Yes, yes.

I tossed out a few more questions. Did he ever talk with her about his writing? No. He wrote during the day, then came into the hotel in the evening when the writing was behind him. I felt my brow furrow a little. I think I had hoped to find some magical key through this question. I pressed on.

Why didn't he write about the south of France, other than the unpublished play The Welcome Table? Well, he wanted to. He had planned to, but he died too soon. He knew it would have to be big, that he would have to go deep into history to get at the fabric of St-Paul. He knew he would have to produce something like Balzac. He didn't get the chance.

St.-Paul has become a little overrun with day-trippers who arrive by the busload. I asked her if it was like this in Baldwin's time. No, no. It's changed dramatically. Pitou blamed it on the new mayor who has courted tourism, and the type of tourist who doesn't want to see anything, who just wants to come look around. As we were talking, such tourists were wandering toward our table in the back of the hotel with cameras. They were grotesque counterparts, I thought, of me with my recorder, hoping to take some relic away from this sacred place.

She remembered all of the personalities around Jimmy's life, too: his brother David, Bernard Hassell who managed the household in Baldwin's waning years, Baldwin's early lover Lucien Happersberger, the one who got away, who was also full of life. Her reminiscences were marked by hilarity. The delightful outrageousness of these people, their bohemian lives. I hung on her stories, on the 
ebullient mood they put her in, which is easy to overlook when one reads Baldwin's public pronouncements in interviews. He was a serious man, a deadly serious man, when it came to talking about race, his nation, history... but the warm, sensitive man she knew balanced that out. Did she ever see him lose his temper? Yes, oh yes. And it was terrifying. But the stories go that he would always apologize afterwards, yes? Mmmmm ... not always.

I pressed on. How did St.-Paul react to him? He was just part of the fabric. They didn't recognize him as a celebrity. He was just who he was, a fixture in town, especially at the Colombe D'Or, brandishing a glass of rosé and a cigarette and an opinion.

Baldwin's a man we won't meet again, none of us. From a time gone by. That's the impression I got talking to Pitou. She slowed down, stopped talking, and stubbed out the last of three cigarettes. "Et voila," were her last words on the subject.

Yes, that's it. Baldwin's ghost is certainly alive in Pitou's memories, but she keeps them largely to herself. There's no plaque in the hotel saying, "James Baldwin drank here!" There's no public commemoration in town indicating that he'd ever been here. There's no physical memory of Baldwin on the place. I wanted to tack a sign on the locked gate in front of his house: "James Baldwin Lived Here." That wasn't my right, though, and I wasn't even sure he would have wanted it. I was beginning to feel like I was overstepping my bounds, encroaching on his privacy, perhaps losing sight of my goal.

I made my way back through the throngs of tourists to get another peek at his house, but the gate remained locked. Uninhabited, from the looks of it. ${ }^{13} \mathrm{~A}$ house is not a home, he said. Something to be manipulated. A place where one lives. Temporarily. A place where one writes. Temporarily.

There was no one else around, apparently, who had known him. Baldwin's spirit was alive in Pitou, at least for the hour when we talked, but his ghost still evaded me. Baldwin had to go where he had to go to get his work done, and to live his life as it needed to be lived. While here, he wrote two major novels and two major works of non-fiction, all about the United States and American culture. This is what began to fascinate me as I skulked through the streets of St.-Paul. For him, it was not a place to write about. It was a place to write from.

Enter the idea of expatriation, especially with writers associated with that word. It tends to be true that such writers look out, look back, look elsewhere when they've found their second home. This is a fairly pat idea when discussing expatriate writers. They need to remove themselves from their milieu in order to write with clarity. But why?

Let's assume perspective is a factor. You might be able to see something when it's up close to your face (if you're not of a certain age), but it's not easy to put it in context.

Let's assume, too, that it's crucial to break from routine. Thoreau produced so many wise insights in Walden not because that mundane little pond is particularly inspiring, but because he wasn't distracted by the nonsense that 
consumed his daily life. Routine has its place, of course, in terms of making our lives efficient and fluid, but it's not necessarily conducive to creative outbursts or deep insights. One must allow or create new space for such things

Let's add inspiration, a word that connotes some creative force that breathes life into you. For writers and other artists, such inspiration comes from surprising quarters, when it comes at all. To change one's setting is to court such surprise.

I kept looking around, feeling like I was missing something. Inspiration in St.-Paul could come from either nature (the sea in the distance, the mountains in the other direction providing a stunning contrast) or culture (the famed Foundation Maeght is only the beginning, as the town itself contains more galleries than every other type of business combined). But these are red herrings. Baldwin was not writing about that kind of nature, nor was he writing his most visually acute works in this period. This was the man who announced early in his career, "One writes out of one thing only-one's own experience." "14 Okay, but the books written in St.-Paul were about American history, American cinema, a pregnant New York teen and her imprisoned boyfriend, a tormented snarl of personal history, and the Atlanta child murders of the late 1970s. Where was St.-Paul in Baldwin's late work, and where was Baldwin in St.-Paul?

I shuffled around trying to figure it out the night after I talked to Pitou. I found a restaurant, sat down to dinner, and looked out over the very valley that he looked over every day, from his "torture chamber." The sun was setting over the mountains. I tried to imagine that the hills leading down to the sea were Baldwin's distinctive furrowed brow, or the surface of his brain. I could almost see him sitting next to me. He broke into one of those remarkable grins at this thought, first raising his eyebrows, then exposing his teeth in an uncontainable laugh. "You really think so?" he guffawed, then, getting serious, he asked, "What are you doing here?" And repeated, with Baldwinian emphasis, "What are you doing. . .here?"

I turned away from his ghost and tried to answer the question for myself. I'm trying to get at something, something that links the writer with a specific place. Baldwin couldn't have written Giovanni's Room if he hadn't gone to Paris: I'm sure of it. And he was following in the footsteps of other writers he admired, notably Henry James, who went abroad and used it. I had asked Pitou about this; she swept away some smoke and said, "It could have been anywhere." I don't accept that, because it was here. He was here.

Back to inspiration, and landscapes. I remember visiting a house in the Berkshires where Melville composed Moby-Dick. The tour guide pointed out that there was a mountain directly across from Melville's window that resembled, if you looked at it the right way, the back of a whale. That's what Melville was staring at those many years. I remember thinking, "Cool!" then thinking, "Wait: does Herman Melville really need a mountain to remind him what a whale looked like? He wrote Moby-Dick, for crying out loud, which was hardly about whales; am I going to accept an explanation that pat?" 
"What are you doing. . here?" Baldwin's spirit repeated, poking my chest. I'm doing what anyone does when visiting a historically significant place. Our world is full of markers that declare, "On this site ... Famous people have lived in this house, a battle was fought on this field, a man nailed a religious proclamation to this church door ... We mark all kinds of sites because history happened in a place, and by being in that place we hope to sense it, to feel it. Satisfied, Jimmy?"

"No," he said, swirling his wine while pointing at me. "Are you? You only answered part of the question. The 'here' part. I didn't ask 'why did you come here."”

Okay. So, deeper. We mark places to say, "History happened here," and in doing so we ensure that nothing historically significant will happen there again. Will anyone ever cure cancer where the Bastille stood in Paris? Obviously not: you can't build a lab on a historically significant site. You can't turn a cemetery into a garden, either. So we find places where we can live, and, as Baldwin said of houses, we "manipulate" them.

I asked for the check and ruminated on the landscape below. Jimmy continued the dialogue with me:

"Did you come here to find me?"

"I thought so."

"And what do you think now?"

"I think I came here to find us."

A smirk. "What do you mean?"

"I think I mean that writers only mean something to readers. I came here because you came here."

"I came here to write."

"So did I."

"So what are you waiting for?" It was like the moment when he grabbed Pitou's wrist and told her to build her life on what has been destroyed. Only much more succinct. I came here to write.

I paid my bill and scurried back to the hotel and got it all down. Et voila.

By way of conclusion, then: expatriation shouldn't be overthought. It's intuition. You feel a pull toward one place and a push from another, and you go, and you stay: longer than a tourist, but not as long as an immigrant. You never become fully integrated into the place: you're somewhere temporarily, and you know it, and yet you don't know for how long you'll be there. Like a house, you use it. It acts upon you at the same time.

Writing can happen anywhere. This is true of most creative acts. But where does it happen? That's all that matters. If it isn't happening somewhere, you have to go somewhere else. I couldn't have written any of this if I didn't travel to St.-Paul-de-Vence, trying to "meet" James Baldwin, which I did, in some mystical way. Once I did, we said our farewells, and he told me I could go home again, but that I should feel free to visit anytime. 


\section{Notes}

1 Magdalena Zaborowska, James Baldwin's Turkish Decade: Erotics of Exile (Durham and London, Duke University Press, 2009).

2 James Baldwin, The Price of the Ticket (New York, St. Martin's, 1985), p. 309; Fred L. Standley and Louis H. Pratt (eds.), Conversations with James Baldwin (Jackson and London, University Press of Mississippi, 1989), p. 178.

3 Robert Coles, "James Baldwin Back Home," The New York Times Book Review, (31 July 1977), p. 14.

4 James Campbell, Talking at the Gates (New York, Viking, 1991), p. 243.

5 Ibid., p. 246.

6 Standley and Pratt, Conversations, p. 154.

7 See "Notes of a Native Son," (1955).

8 James Baldwin, Collected Essays (Washington, D.C., The Library of America, 1998), p. 774 .

9 Standley and Pratt, Conversations, p. 153.

10 James Baldwin, “The Architectural Digest Visits: James Baldwin,” Architectural Digest (August 1987), pp. 123-5.

11 Campbell, Talking, p. 264.

12 David Leeming, James Baldwin (New York, Knopf, 1994), pp. 372-88.

13 In her essay "James Baldwin's Global Imagination," Magdalena Zaborowska writes, "It was shocking to see my favorite author's domestic space in a state of disarray, disrepair, and abandonment," in Michele Elam (ed.), The Cambridge Companion to James Baldwin (Cambridge, Cambridge UP, 2015), p. 141.

14 Baldwin, "Autobiographical Notes," Collected Essays, p. 8.

\section{Works Cited}

Baldwin, James, The Price of the Ticket (New York, St. Martin's, 1985).

"The Architectural Digest Visits: James Baldwin," Architectural Digest (August 1987), pp. 123-5.

"Autobiographical Notes," (1955) in Collected Essays (New York, Library of America, 1998), pp. 5-10.

"Notes of a Native Son," (1955) in Collected Essays (New York, Library of America, 1998), pp. 63-84.

Campbell, James, Talking at the Gates: A Life of James Baldwin (New York, Viking, 1991).

Coles, Robert, "James Baldwin Back Home," The New York Times Book Review (31 July 1977), p. 14.

Leeming, David, James Baldwin: A Biography (New York, Alfred A. Knopf, 1994).

Standley, Fred L. and Pratt, Louis H. (eds.), Conversations with James Baldwin (Jackson and London, University Press of Mississippi, 1989).

Zaborowska, Magdalena, James Baldwin's Turkish Decade: Erotics of Exile (Durham and London, Duke University Press, 2009).

"James Baldwin's Global Imagination," in Michele Elam (ed.), The Cambridge Companion to James Baldwin (Cambridge, Cambridge University Press, 2015). 


\section{Contributor's Biography}

D. Quentin Miller is Professor and chair of English at Suffolk University in Boston. He is the author of "A Criminal Power": James Baldwin and the Law (Ohio State UP, 2012), the editor of Re-Viewing James Baldwin: Things Not Seen (Temple UP, 2000), and the author of more than two dozen articles and reference volume entries on Baldwin. His forthcoming books are The Routledge Introduction to African American Literature, American Literature in Transition: 1980-90, and Understanding John Edgar Wideman. 